\title{
Primary chemotherapy with gemcitabine, epirubicin and taxol (GET) in operable breast cancer: a phase II study
}

\author{
PF Conte ${ }^{*, I}$, S Donati ${ }^{2}$, A Gennari ${ }^{2}$, V Guarneri' ${ }^{1}$, C Orlandini ${ }^{2}$, M Rondini $^{2}$, M Roncella ${ }^{3}$, L Marini ${ }^{4}$, P Collecchi ${ }^{5}$,

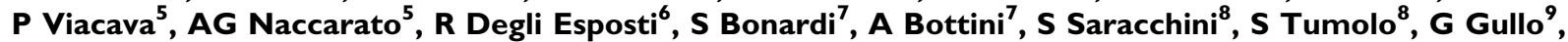 \\ A Santoro' and L Crino ${ }^{6}$
}

'Department of Medical Oncology and Hematology, University of Modena and Reggio Emilia, Modena, Italy; ${ }^{2}$ Division of Oncology, S Chiara University Hospital, Pisa, Italy; ${ }^{3}$ Division of Surgery, S Chiara University Hospital, Pisa, Italy; ${ }^{4}$ Eli Lilly Italy, Medical Department, Firenze, Italy; ${ }^{5}$ Division of Pathology, S Chiara University Hospital, Pisa; Italy; ' Division of Medical Oncology, Bellaria Hospital, Bologna, Italy; ${ }^{7}$ Breast Unit, Istituti Ospitalieri, Cremona, Italy; ${ }^{8}$ Division of Oncology, S Maria Angeli Hospital, Pordenone, Italy; ${ }^{9}$ Division of Oncology, Istituto Clinico Humanitas, Rozzano, Italy

This trial was conducted to assess the activity and tolerability of the gemcitabine, epirubicin, taxol triplet combination in patients with operable breast cancer. After core biopsy, 43 women with stage II-IIIA breast cancer were treated with gemcitabine $1000 \mathrm{mg} \mathrm{m}^{-2}$ over 30 min on days I and 4, epirubicin $90 \mathrm{mg} \mathrm{m}^{-2}$ as an intravenous bolus on day I, and taxol $175 \mathrm{mg} \mathrm{m}^{-2}$ as a 3-h infusion on day I, every 21 days for four cycles. The primary end point was the percentage of pathological complete responses ( $p C R$ ) in the breast; secondary end points were tolerability, clinical response rates, overall and progression-free survival, tumour biomarkers before and after primary chemotherapy (PCT). All patients were included in safety and survival analyses; $4 \mathrm{I}$ eligible patients were evaluated for response. The overall clinical response rate was $87.8 \%$ (95\% Cl 77.8-97.8), with 26.8\% complete responses (95\% Cl I3.3-40.3). $\mathrm{A}$ PCR in the breast was observed in six patients ( $14.6 \%$; $95 \% \mathrm{Cl} 3.8-25.4)$; I 5 patients (36.6\%; $95 \% \mathrm{Cl} 21.9-51.3)$ had negative axillary lymph nodes. Grade 4 neutropenia was observed in $67.4 \%$ of the patients; febrile neutropenia occurred in $1.9 \%$ of cycles (granulocyte colony-stimulating factor was used in $3.2 \%$ of the cycles to shorten the duration of neutropenia). A statistically significant difference between Mib-I at baseline ( $\geqslant 20 \%$ in $71.4 \%$ of the patients) and at definitive surgery $(28.6 \%, P<0.05)$ was observed. The gemcitabine, epirubicin, taxol regimen is active and well tolerated as PCT for operable breast cancer. This combination allows the administration of full doses of active agents with a low incidence of febrile neutropenia.

British Journal of Cancer (2005) 93, 406-4I I. doi: I0.1038/sj.bjc.6602723 www.bjcancer.com

Published online 26 July 2005

(C) 2005 Cancer Research UK

Keywords: gemcitabine; epirubicin; taxol; breast cancer; primary chemotherapy; pathological complete response

Primary chemotherapy (PCT) was initially employed to treat locally advanced and/or inflammatory breast carcinomas. An objective response was observed in more than $50 \%$ of the patients, radical surgery was feasible in most of the cases, and prolonged disease-free and overall survival were reported (Hortobagyi and Buzdar, 1997; Ueno et al, 1997; Baldini et al, 2003). More recently, PCT has been used in patients with large primary tumours to avoid radical mastectomy. Again, a significant proportion of patients experienced an objective response and could be treated with conservative surgery (Bonadonna et al, 1990, 1998; Smith et al, 1995; Mauriac et al, 1999). Interestingly, in about $10 \%$ of cases, tumour shrinkage was so massive that no viable tumour cells were found at definitive pathology; the achievement of a pathological complete response (pCR) was associated with a prolonged diseasefree and overall survival (Fisher et al, 1998; Kuerer et al, 1999; Pierga et al, 2000). So far, randomised clinical trials have failed to show a survival advantage for PCT vs postoperative treatment; however, other advantages such as the increased rate of breast

*Correspondence: Dr PF Conte; E-mail: conte.pierfranco@unimore.it Received 14 April 2005; revised 24 June 2005; accepted 28 June 2005; published online 26 July 2005 conservative surgery and the prognostic value of pCRs have been confirmed (Scholl et al, 1994; Fisher et al, 1997; Kuerer et al, 1999; Pierga et al, 2000; van der Hage et al, 2001; Mauri et al, 2005).

Primary chemotherapy is now considered the standard treatment for locally advanced and inflammatory breast carcinoma, a reasonable approach for operable breast cancer with unfavourable breast/tumour ratio and an acceptable alternative for all early breast cancer patients who are candidates for adjuvant chemotherapy.

Apart from these established roles in routine practice, PCT represents an interesting research tool which allows investigators to: (1) test new regimens with a validated short-term end point (pCR); (2) design tailored treatments based on the observed response; (3) identify tumour biomarkers with prognostic and/or predictive value.

We have recently shown that the combination of gemcitabine plus epirubicin and taxol (GET) is feasible and extremely active in metastatic breast cancer (Conte et al, 2001; Cappuzzo et al, 2004). Based on the high overall and complete response rates obtained with this regimen, we have designed a phase II trial to evaluate the activity of GET as PCT in operable breast cancer. An ancillary study was the evaluation of the tumour biological profile before and after chemotherapy. In particular, markers of proliferation have already been validated as valuable predictors of response to 
both PCT and endocrine therapy, and were therefore included in our study (Esteva and Hortobagyi, 2004; Burcombe et al, 2005; Dowsett et al, 2005).

Preliminary results from this trial have been previously reported (Conte et al, 2003).

\section{PATIENTS AND METHODS}

Patients with histologic diagnosis of breast cancer who met the following criteria were eligible: stage II - IIIa (tumour size $\geqslant 2 \mathrm{~cm}$ ) determined by physical examination and mammography; adequate bone marrow reserve (white blood cell count $\geqslant 4.0 \times 10^{9} 1^{-1}$, platelets $\geqslant 100 \times 10^{9} \mathrm{l}^{-1}$, haemoglobin $\left.\geqslant 100 \mathrm{gl}^{-1}\right)$; adequate renal and hepatic function (creatinine $<1.5 \mathrm{mg} \mathrm{dl}^{-1}$, alanine transaminase or aspartate transaminase $<1.5$ upper limit of normal (ULN)); normal cardiac function determined by electrocardiogram and left ventricular ejection fraction (L-VEF); World Health Organization (WHO) performance status $\leqslant 2$; aged $18-70$ years; compliance and geographic proximity; childbearing potential terminated or attenuated by use of an approved contraceptive method; written informed consent. The noneligibility criteria were: locally advanced disease (stage IIIB) or inflammatory breast carcinoma; multifocal breast carcinoma; active infection; calcium above the ULN; presence of distant metastases; other serious medical illness (including history of congestive heart failure, myocardial infarction, symptomatic cardiac arrhythmias). Prestudy staging included physical examination, mammography and/or ultrasonography of the breast, chest radiography, bone scan, liver ultrasonography, echocardiography and haematological blood tests.

\section{Treatment plan}

After core biopsy, patients were treated according to the following schedule: gemcitabine $1000 \mathrm{mg} \mathrm{m}^{-2}$ over $30 \mathrm{~min}$ on days 1 and 4 , epirubicin $90 \mathrm{mg} \mathrm{m}^{-2}$ as an intravenous (i.v.) bolus on day 1 and taxol $175 \mathrm{mg} \mathrm{m}^{-2}$ as a 3 -h infusion on day 1 , every 21 days for four cycles. In order to prevent severe hypersensitivity reactions, patients received a premedication with dexamethasone $20 \mathrm{mg}$ i.m., orphenadrine $50 \mathrm{mg}$ i.m. and cimetidine $300 \mathrm{mg}$ i.v.

Complete blood count was determined on day one of each cycle and then twice a week. Treatment was permitted if white blood cell count was $\geqslant 3.0 \times 10^{9} 1^{-1}$, absolute neutrophil count was $\geqslant 1.5 \times 10^{9} 1^{-1}$ and platelet count was $\geqslant 100 \times 10^{9} 1^{-1}$; if these values were not reached, treatment was delayed until recovery. All drugs were reduced by $25 \%$ in case of febrile neutropenia requiring hospitalisation and/or i.v. antibiotics, grade 4 thrombocytopenia lasting more than 3 days and/or associated with bleeding, or grade 4 neutropenia lasting more than 7 days. In case of grade 3 nonhaematological toxicities (except nausea/vomiting and alopecia), all drugs were reduced by $25 \%$; all drugs were reduced by $50 \%$ for grade 4 toxicity. In the case of grade 1 neurotoxicity, taxol was reduced to $135 \mathrm{mg} \mathrm{m}^{-2}$, and in the case of grade 2 neurotoxicity, taxol was discontinued. The protocol permitted use of granulocyte colony-stimulating factor (G-CSF) as prophylaxis after episodes of febrile neutropenia. Patients with hypersensitivity reactions received supportive measures and were treated again with taxol at a slower rate of infusion.

Patients who developed progressive disease were taken off the study.

\section{Surgery}

After four cycles of chemotherapy, breast surgery was performed according to local procedures. Patients received either modified radical mastectomy or lumpectomy with axillary dissection of level I-II axillary lymph nodes.

\section{Adjuvant therapy}

Adjuvant postoperative chemotherapy was left to the discretion of the treating physician; however, two additional courses of chemotherapy were recommended in cases of positive lymph nodes. Premenopausal receptor-positive patients received tamoxifen $20 \mathrm{mg}$ daily for 5 years plus luteinising hormone-releasing hormone inhibitors for 2 years. Postmenopausal receptor-positive patients received tamoxifen $20 \mathrm{mg}$ daily for 5 years.

In cases of breast conservative surgery, postoperative irradiation with a $4-6 \mathrm{MeV}$ linear accelerator or modern cobalt-60 unit was administered. Radiotherapy was started after completing chemotherapy.

\section{Study analysis}

Assessment of response Clinical assessment of tumour and nodal size was performed by physical examination, mammography and/ or ultrasonography before starting chemotherapy, and again before surgery.

Clinical response was defined as follows: complete response is the disappearance of all clinically detectable disease; partial response is $a \geqslant 50 \%$ decrease in the products of the two largest tumour diameters; stable disease reflects changes in tumour burden that do not indicate a progressive disease or clinical complete or partial response. Progressive disease was defined as at least a $25 \%$ increase in the sum of the products of bidimensionally measurable disease or the appearance of new lesions.

Pathological complete response was defined as no histologic evidence of invasive or noninvasive tumour cells in the breast. Toxicity was evaluated according to the common toxicity criteria of the National Cancer Institute. Progression-free and overall survivals were calculated according to Kaplan-Meier curves from day 1 of the first cycle. All registered patients were included in the analysis of toxicities and survival. Eligible patients only were included in the primary efficacy analysis.

Biological study The following biological markers were assayed at baseline and on the surgical specimens: hormone receptor, Mib-1, Scarff-Bloom-Richardson grade and Her-2-neu expression. All the biological markers were measured in a centralised laboratory.

End points The primary end point was the pCR rate. Secondary end points were: toxicities, overall response rate, survival and progression-free survival, and tumour biological profile before and after PCT.

Statistical methods Simon's optimal two-stage design for phase II clinical trial was used to calculate the sample size, with the principal study end point being the PCR rate. The sample size was calculated on the following assumptions: $\alpha$ error $=0.05$, $\beta$ error $=0.10 ; P_{0}$ (clinically uninteresting true response rate) and $P_{1}$ (sufficiently promising true response rate) were set at 5 and $20 \%$, respectively. In all, 21 patients had to be enrolled in the first stage: if $\leqslant 1$ pCR were observed, the accrual was stopped. In case of $\geqslant 2$ pCR, 20 more patients were entered at the second stage. The regimen was considered sufficiently active to deserve further studies if $\geqslant 5$ pCRs were seen.

\section{RESULTS}

\section{Patient characteristics}

A total of 44 women with stage II-IIIA disease from five Italian institutions were enrolled into the study; one patient was not included in the full analysis set for refusal. In all, 41 patients were eligible, two patients were not included in the primary efficacy analysis due to the existence of bilateral breast carcinoma. The 
characteristics of the patients are shown in Table 1 . The median age was 48 years (range 26-66 years); the majority of patients had stage II disease $(67.4 \%)$ and positive hormone receptors $(79.1 \%)$. Baseline hormonal status was not available in one patient who achieved a pCR. Median tumour size at the baseline was $4 \mathrm{~cm}$ (range $2-7 \mathrm{~cm}$ ). Mib-1 was $\geqslant 20 \%$ in $23(53.5 \%),<20 \%$ in 13 $(30.2 \%)$ and not known in seven patients. Her-2 status was positive in five (11.6\%), negative in $25(58.1 \%)$ and unknown in 13 patients.

\section{Response to chemotherapy}

All eligible patients were evaluable for response. The overall clinical response rate was $87.8 \%$ (95\% CI $77.8-97.8$ ), with $61 \%$ of the patients experiencing a partial response and $26.8 \%$ (95\% CI $13.3-40.3)$ a complete response; stable disease was observed in five patients (12.2\%).

Table I Patient characteristics

\begin{tabular}{lc}
\hline Number of patients enrolled & 44 \\
Patients eligible & 41 \\
Median age (range) & $48(26-66)$ \\
Median tumour size, cm (range) & $4(2-7)$ \\
& \\
Hormonal receptor status, n (\%) & \\
Positive & $34(79.1)$ \\
Negative & $8(18.6)$ \\
Unknown & $1(2.3)$ \\
Mib-I status, n (\%) & \\
Positive ( $\geqslant 20 \%)$ & $23(53.5)$ \\
Negative (<20\%) & $13(30.2)$ \\
Unknown & $7(16.3)$ \\
Her 2 status, $n(\%)$ & \\
Positive & \\
Negative & $5(11.6)$ \\
Unknown & $25(58.1)$ \\
\hline
\end{tabular}

A pCR was observed in six patients (14.6\%) (95\% CI 3.8-25.4); 15 patients $(36.6 \%)(95 \%$ CI $21.9-51.3)$ had negative axillary lymph nodes.

The pCR rate was analysed as a function of pretreatment clinical stage and biological characteristics. Two pCRs were observed among five patients with tumours less than $3 \mathrm{~cm}(40 \%)$, three among 25 women with tumour size between 3 and $5 \mathrm{~cm}(12 \%)$, and one in 11 patients with tumours larger than $5 \mathrm{~cm}(9.1 \%)$. The pCR rate was $9.7 \%$ (three out of 32 ) in oestrogen receptor-positive and $25 \%$ (two out of eight) in oestrogen receptor-negative tumours, $17.4 \%$ (four out of 23 ) in Mib-1 $\geqslant 20$ and $7.7 \%$ (one out of 13 ) in Mib- $1<20 \%$ tumours, $20 \%$ (one out of five) and $4 \%$ (one out of 25) in Her-2-positive and -negative tumours, respectively; none of these differences reached statistical significance.

At a median followup of 29 months (range 12.2-51), nine patients had developed progressive disease and three patients had died (Figure 1).

\section{Toxicity}

In all, 43 patients were evaluable for toxicity. During the study, 172 cycles of chemotherapy were administered and were evaluable for toxicity.

The main haematological toxicity was neutropenia, with grade 4 episodes observed in $67.4 \%$ of the patients. Febrile neutropenia occurred in $1.9 \%$ of cycles, while G-CSF was administered in $3.2 \%$ of the cycles to shorten the duration of neutropenia. Only one episode of grade 3 anaemia was observed, while thrombocytopenia was mild, with $9.3 \%$ of patients experiencing a grade 3 toxicity (Table 2). One red blood cell transfusion was performed, but no platelet transfusion was required. Delays and dose reductions were performed in 10.3 and $9.7 \%$ of the cycles, respectively. The administered dose intensity of each individual drug was 95, 98 and 97\% for gemcitabine, epirubicin and taxol, respectively.

No episode of grade 4 nonhaematological toxicity occurred. Nausea/vomiting and mucositis grade 3 were observed in 9.3 and $7 \%$ of the patients, respectively. Grade 1-2 neuropathy was observed in $18.6 \%$ of the patients. Cutaneous toxicity was mild,

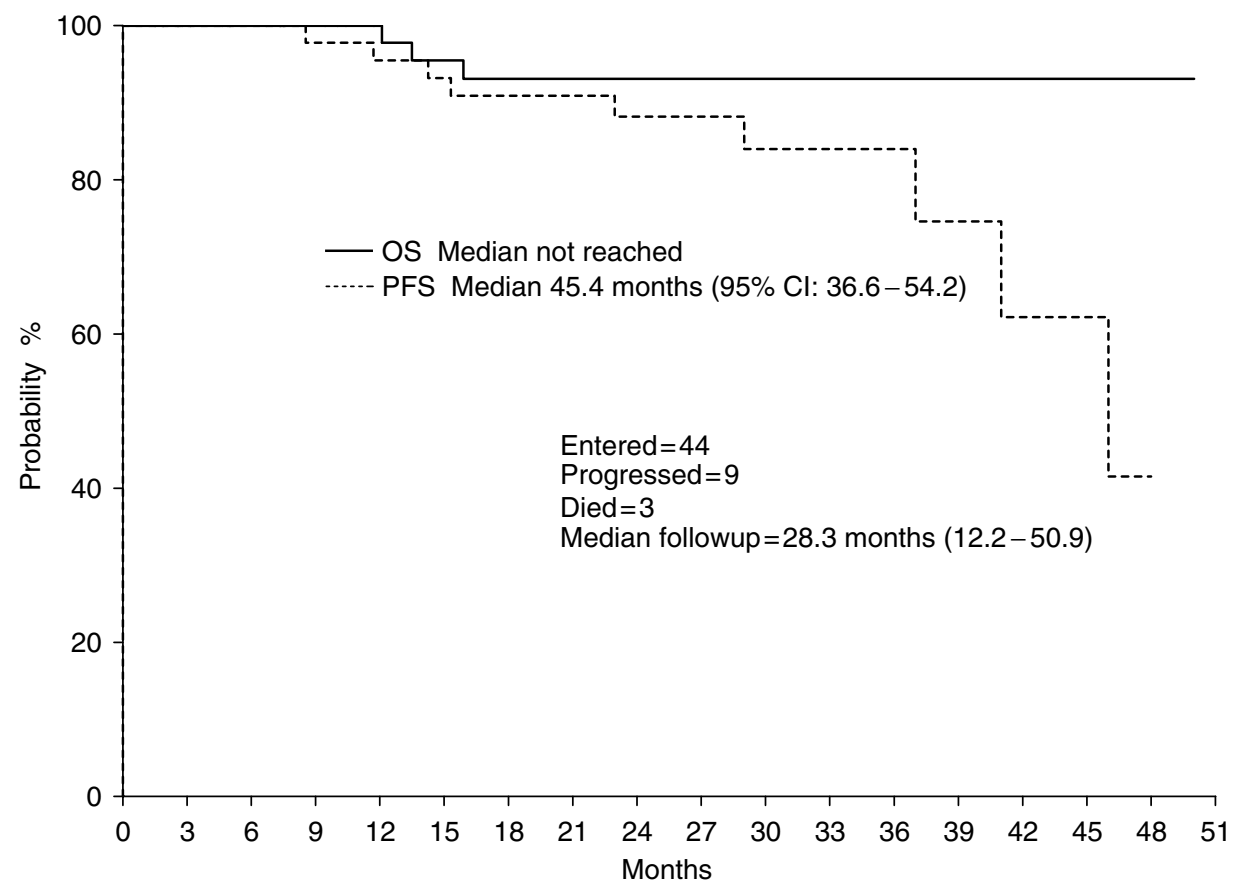

Figure I Progression-free survival and overall survival. 
Table 2 Haematological toxicity (\% of patients)

\begin{tabular}{lcccc}
\hline & Grade I & Grade 2 & Grade 3 & Grade 4 \\
\hline Anaemia & 53.5 & 27.9 & 2.3 & - \\
Neutropenia & 2.3 & 9.3 & 16.3 & 67.4 \\
Leucopenia & 7.0 & 30.2 & 44.2 & 14.0 \\
Thrombocytopenia & 34.9 & 16.3 & 9.3 & - \\
\hline
\end{tabular}

Table 3 Non-haematological toxicity (\% of patients)

\begin{tabular}{lcccc}
\hline & Grade I & Grade 2 & Grade 3 & Grade 4 \\
\hline Nausea/vomiting & 39.5 & 37.2 & 9.3 & - \\
Mucositis & 27.9 & 9.3 & 7.0 & - \\
Paresthesias & 16.3 & 2.3 & - & - \\
Cutaneous & 27.9 & 14.0 & - & - \\
Diarrhoea & 11.6 & 0.0 & 2.3 & - \\
Alopecia & - & 4.7 & 95.3 & - \\
\hline
\end{tabular}

Table 4 Modification of tumour phenotype

\begin{tabular}{lccr}
\hline & $\begin{array}{c}\text { Pretreatment } \\
\text { (\% of patients) }\end{array}$ & $\begin{array}{c}\text { Post-treatment } \\
\text { (\% of patients) }\end{array}$ & P \\
\hline Oestrogen-receptor & 69.7 & 73.9 & 0.90 \\
positive & 68.5 & 72.7 & 0.96 \\
Grade 3 & 71.4 & 28.6 & $<0.05$ \\
Mib | $\geqslant 20 \%$ & 21.0 & 10.5 & 0.46 \\
Her-2 neu & & & \\
\hline
\end{tabular}

with $41.9 \%$ of the patients experiencing grade 1-2 toxicity (Table 3).

No clinical cardiac toxicity or significant decrease of L-VEF was observed.

\section{Surgery}

All the patients underwent surgery for breast cancer. In all, 19 patients $(44 \%)$ were treated with lumpectomy and axillary node dissection, and 24 patients $(56 \%)$ received modified radical mastectomy.

\section{Biological study}

The expression of hormonal receptor status and nuclear grading were not modified by chemotherapy. A statistically significant difference between Mib-1 at baseline and at definitive surgery was observed: Mib- $1 \geqslant 20 \%$ in $71.4 \%$ of the patients at baseline and in $28.6 \%$ at surgery $(P<0.05)$. Her-2-neu expression was also modified by chemotherapy even if the difference was not significant: it was positive in $21 \%$ of the patients at baseline and in $10.5 \%$ at surgery. Biological data are summarised in Table 4.

\section{DISCUSSION}

International recommendations have been developed to support the use of PCT in routine practice (Kaufmann et al, 2003); however, this approach still represents an interesting research tool that allows a reliable intermediate end point such as pCR to be measured, treatments to be designed and tailored on response, and tumour biomarkers with potential prognostic or predictive value to be investigated. Our study was designed to assess the efficacy and tolerability of the GET regimen as PCT in operable breast carcinoma. This combination was initially tested in metastatic breast cancer patients, showing an interesting activity with response rates ranging from 62 to $92 \%$, with $10-31 \%$ CR (Conte et al, 2001; Zielinski et al, 2003; Cappuzzo et al, 2004). This regimen was found to be well tolerated. The majority of the patients experienced a grade 4 neutropenia; however, the incidence of febrile neutropenia was very low $(5-12 \%)$ and growth factors were rarely used.

This trial confirms that the GET regimen can be safely administered at full doses with a few patients requiring dose adjustments. The incidence of grade 4 neutropenia was high (67.4\% of the patients); however, it was short lasting, rarely requiring G-CSF administration (3.2\% of cycles), and resulted in very few episodes of febrile neutropenia ( $1.9 \%$ of cycles), significantly lower than that observed in an adjuvant trial with a three-drug regimen including docetaxel, doxorubicin and cyclophosphamide (Martin et al, 2003). The reduced myelotoxicity of paclitaxel $v s$ docetaxel, epirubicin $v s$ doxorubicin, gemcitabine $v s$ cyclophosphamide, and the lack of negative pharmacokinetic interference explain the good tolerability of the GET regimen (Fogli et al, 2002). The more favourable patient characteristics (younger median age, excellent performance status) and the shorter treatment duration (four courses in the present trial, six to eight courses in the GET trials in advanced breast cancer) can explain the extremely low incidence of febrile neutropenia observed in the present trial in comparison to the other trials with the GET regimen (Conte et al, 2001; Zielinski et al, 2003; Cappuzzo et al, 2004).

The primary aim of our study was to evaluate the activity of the GET combination. The overall response rate was $87.8 \%$, with $26.8 \%$ clinical complete remissions and $14.6 \%$ pCRs.

Conservative surgery was not an end point of the study and no guideline for conservative surgery was included in the protocol; this reason and the fact that the patients were treated in five different hospitals may explain the relatively low percentage of conservative surgery $(44 \%)$. The high activity of this triplet regimen has been confirmed by Hamm et al (2003) in locally advanced breast cancer, and by Schneeweiss et al (2004) in operable breast cancer. In this last trial, paclitaxel was substituted with docetaxel $\left(75 \mathrm{mg} \mathrm{m}^{-2}\right)$, the dose of gemcitabine was reduced to $800 \mathrm{mg} \mathrm{m}^{-2}$ on days 1 and 8 , epirubicin was administered at $90 \mathrm{mg} \mathrm{m}^{-2}$ and filgrastim support was required.

Comparable pCR rates have been obtained with other regimens containing taxanes, anthracyclines or antimetabolites (Gradishar, 1997; Ganem et al, 2003; Dieras et al, 2004; Lebowitz et al, 2004; Smith et al, 2004). Differences in patient selection, tumour size and characteristics, treatment duration and pathological classification of response make any comparison impossible. It is, however, of interest that the GET regimen allows the concurrent administration of full doses of active drugs, thus producing results comparable to those obtained with more prolonged sequential schedules (Gianni et al, 2002; Smith et al, 2002; Bear et al, 2003; von Minckwitz et al, 2003).

Primary chemotherapy provides the ideal setting to investigate prognostic and predictive factors; apart from pCR, the most powerful predictor of long-term outcome is the status of axillary lymph nodes. In our study, $36.6 \%$ of the patients had negative axillary lymph nodes at surgery. However, the nodal status was not pathologically documented at study entry, and it is therefore impossible to measure the effect of treatment on this parameter. Many predictive factors of response have been studied, and several authors have reported that hormone receptor negativity, high histological grade and high Ki-67 levels correlate with pCR, while the predictive value of Her 2 expression, bcl-2 and p53 status is still unclear (Archer et al, 1995; Makris et al, 1997; Chang et al, 1999; Colleoni et al, 1999; Ellis et al, 2001; Petit et al, 2001). In our study the probability of pCR was higher, even if statistically not significant, in the case of hormone receptor-negative tumours 
(25 vs 9.7\%), Mib-1 $\geqslant 20 \%(17.4$ vs $7.7 \%$ ) and Her-2 overexpression (20 vs 4\%).

Availability of tumour tissue before, during and after PCT allows for the possibility of measuring biomarker expression during treatment and, potentially, correlating the observed modifications with outcome. In particular, the tumour-proliferative rate measured as Ki-67, Mib-1 or thymidine labelling index is rapidly and significantly inhibited by hormonal treatment or chemotherapy (Collecchi et al, 1998; Colleoni et al, 1999; Archer et al, 2003). We have previously reported in locally advanced breast cancer studies that inhibition of tumour proliferation after PCT predicts a better outcome (Collecchi et al, 1998). In this study, we have shown that Mib-1 level was significantly lower after four courses of GET (Mib-1 $\geqslant 20 \%$ in 71.4 and in $21.6 \%$ of the patients before and after chemotherapy, respectively, $P<0.05$ ); however, the limited sample size and the low number of events do not allow this finding to be correlated with patient outcome.

Primary chemotherapy can facilitate the development of treatments tailored on the quality of response (pCR $v s$ non-pCR) and biomarker expression and modulation. In this setting, the expression of gene profile measured by DNA microarray offers the opportunity to identify predictive markers of response; this allows us to identify the patients who benefit from the treatment and to spare unnecessary toxicities to those with de novo resistant tumours (Buchholz et al, 2002; van de Vijver et al, 2002; van't Veer et al, 2002; Chang et al, 2003; Pusztai et al, 2003).

In conclusion, we have shown that four courses of preoperative GET are safe and highly active in patients with early-stage breast cancer. This tolerability is worth noting, taking into account that all drugs were administered at nearly full doses, and this regimen can represent an alternative to the sequential administration of myelotoxic drugs. However, in order to exploit all the opportunities offered by preoperative treatments, a coordinated multidisciplinary approach including clinical oncologists, pathologists and molecular biologists is required (Buchholz et al, 2003).

\section{ACKNOWLEDGEMENTS}

This work was supported in part by a grant from the National Research Council, Rome (CNR - Progetto Strategico Oncologia, grant CU03.00377) and from Eli-Lilly Italy. Dr Donati is supported by a fellowship of the Italian Association for Cancer Research (AIRC).

\section{REFERENCES}

Archer CD, Parton M, Smith IE, Ellis PA, Salter J, Ashley S, Gui G, Sacks N, Ebbs SR, Allum W, Nasiri N, Dowsett M (2003) Early changes in apoptosis and proliferation following primary chemotherapy for breast cancer. Br J Cancer 89: 1035-1041

Archer SG, Eliopoulos A, Spandidos D, Barnes D, Ellis IO, Blamey RW, Nicholson RI, Robertson JF (1995) Expression of ras, p21, p53 and c-erbB-2 in advanced breast cancer and response to first line hormonal therapy. $\mathrm{Br} J$ Cancer 72: $1259-1266$

Baldini E, Gardin G, Giannessi PG, Evangelista G, Roncella M, Prochilo T, Collecchi P, Rosso R, Lionetto R, Bruzzi P, Mosca F, Conte PF (2003) Accelerated $v s$ standard cyclophosphamide, epirubicin and 5-fluorouracil or cyclophosphamide, methotrexate and 5-fluorouracil: a randomized phase III trial in locally advanced breast cancer. Ann Oncol 14: $227-232$

Bear HD, Anderson S, Brown A, Smith R, Mamounas EP, Fisher B, Margolese R, Theoret H, Soran A, Wickerham DL, Wolmark N, National Surgical Adjuvant Breast and Bowel Project Protocol B-27 (2003) The effect on tumor response of adding sequential preoperative docetaxel to preoperative doxorubicin and cyclophosphamide: preliminary results from National Surgical Adjuvant Breast and Bowel Project Protocol B-27. J Clin Oncol 21: 4165-4174

Bonadonna G, Valagussa P, Brambilla C, Ferrari L, Moliterni A, Terenziani M, Zambetti M (1998) Primary chemotherapy in operable breast cancer: eight-year experience at the Milan Cancer Institute. J Clin Oncol 16: $93-100$

Bonadonna G, Veronesi U, Brambilla C, Ferrari L, Luini A, Greco M, Bartoli C, Coopmans de Yoldi G, Zucali R, Rilke F, Andreola S, Silvestrini R, Di Fronzo G, Valagussa P (1990) Primary chemotherapy to avoid mastectomy in tumors with diameters of three centimeters or more. J Natl Cancer Inst 82: 1539-1545

Buchholz TA, Hunt KK, Whitman GJ, Sahin AA, Hortobagyi GN (2003) Neoadjuvant chemotherapy for breast carcinoma: multidisciplinary considerations of benefits and risks. Cancer 98: 1150-1160

Buchholz TA, Stivers DN, Stec J, Ayers M, Clark E, Bolt A, Sahin AA, Symmans WF, Hess KR, Kuerer HM, Valero V, Hortobagyi GN, Pusztai L (2002) Global gene expression changes during neoadjuvant chemotherapy for human breast cancer. Cancer J 8: $461-468$

Burcombe RJ, Makris A, Richman PI, Daley FM, Noble S, Pittam M, Wright D, Allen SA, Dove J, Wilson GD (2005) Evaluation of ER, PgR, HER-2 and Ki-67 as predictors of response to neoadjuvant anthracycline chemotherapy for operable breast cancer. Br J Cancer 92: 147-155

Cappuzzo F, Mazzoni F, Gennari A, Donati S, Salvadori B, Orlandini C, Cetto GL, Molino A, Galligioni E, Mansutti M, Tumolo S, Lucentini A, Valduga F, Bartolini S, Crino L, Conte PF (2004) Multicentric phase II

trial of gemcitabine plus epirubicin plus paclitaxel as first-line chemotherapy in metastatic breast cancer. Br J Cancer 90: 31 - 35

Chang J, Powles TJ, Allred DC, Ashley SE, Clark GM, Makris A, Assersohn L, Gregory RK, Osborne CK, Dowsett M (1999) Biologic markers as predictors of clinical outcome from systemic therapy for primary operable breast cancer. J Clin Oncol 17: 3058-3063

Chang JC, Wooten EC, Tsimelzon A, Hilsenbeck SG, Gutierrez MC, Elledge R, Mohsin S, Osborne CK, Chamness GC, Allred DC, O’Connell P (2003) Gene expression profiling for the prediction of therapeutic response to docetaxel in patients with breast cancer. Lancet 362: 362-369

Collecchi P, Baldini E, Giannessi P, Naccarato AG, Passoni A, Gardin G, Roncella M, Evangelista G, Bevilacqua G, Conte PF (1998) Primary chemotherapy in locally advanced breast cancer (LABC): effects on tumour proliferative activity, bcl-2 expression and the relationship between tumor regression and biological markers. Eur J Cancer 34: $1701-1704$

Colleoni M, Orvieto E, Nole F, Orlando L, Minchella I, Viale G, Peruzzotti G, Robertson C, Noberasco C, Galimberti V, Sacchini V, Veronesi P, Zurrida S, Orecchia R, Goldhirsch A (1999) Prediction of response to primary chemotherapy for operable breast cancer. Eur J Cancer 35: $574-579$

Conte PF, Gennari A, Donati S, Salvadori B, Baldini E, Bengala C, Pazzagli I, Orlandini C, Danesi R, Fogli S, Del Tacca M (2001) Gemcitabine plus epirubicin plus taxol (GET) in advanced breast cancer: a phase II study. Breast Cancer Res Treat 68: $171-179$

Conte PF, Gennari A, Santoro A, Bottini A, Crino L, Tumolo S, Donati S, Rondini M, Orlandini C, Marini L, for the GET Preoperative Group (2003) Induction chemotherapy in operable breast cancer: a multicenter Italian phase II study with the GET regimen. Proc Am Soc Clin Oncol 22 35 (abstract 140)

Dieras V, Fumoleau P, Romieu G, Tubiana-Hulin M, Namer M, Mauriac L, Guastalla JP, Pujade-Lauraine E, Kerbrat P, Maillart P, Penault-Llorca F, Buyse M, Pouillart P (2004) Randomized parallel study of doxorubicin plus paclitaxel and doxorubicin plus cyclophosphamide as neoadjuvant treatment of patients with breast cancer. J Clin Oncol 22: 4958-4965

Dowsett M, Ebbs SR, Dixon JM, Skene A, Griffith K, Boeddinghaus I, Salter J, Detre S, Hills M, Ashley S, Francis S, Walsh G, Smith IE (2005) Biomarker changes during neoadjuvant anastrozole, tamoxifen, or the combination: influence of hormonal status and HER-2 in breast cancer a study from the IMPACT trialists. J Clin Oncol 23: 2477-2492

Ellis MJ, Coop A, Singh B, Mauriac L, Llombart-Cussac A, Janicke F, Miller WR, Evans DB, Dugan M, Brady C, Quebe-Fehling E, Borgs M (2001) Letrozole is more effective neoadjuvant endocrine therapy than tamoxifen for ErbB-1- and/or ErbB-2-positive, estrogen receptor-positive 
primary breast cancer: evidence from a phase III randomized trial. J Clin Oncol 19: $3808-3816$

Esteva FJ, Hortobagyi GN (2004) Prognostic molecular markers in early breast cancer. Breast Cancer Res 6: 109-118

Fisher B, Brown A, Mamounas E, Wieand S, Robidoux A, Margolese RG, Cruz Jr AB, Fisher ER, Wickerham DL, Wolmark N, DeCillis A, Hoehn JL, Lees AW, Dimitrov NV (1997) Effect of preoperative chemotherapy on local-regional disease in women with operable breast cancer: findings from National Surgical Adjuvant Breast and Bowel Project B-18. J Clin Oncol 15: $2483-2493$

Fisher B, Bryant J, Wolmark N, Mamounas E, Brown A, Fisher ER, Wickerham DL, Begovic M, DeCillis A, Robidoux A, Margolese RG, Cruz Jr AB, Hoehn JL, Lees AW, Dimitrov NV, Bear HD (1998) Effect of preoperative chemotherapy on the outcome of women with operable breast cancer. J Clin Oncol 16: 2672-2685

Fogli S, Danesi R, Gennari A, Donati S, Conte PF, Del Tacca M (2002) Gemcitabine, epirubicin and paclitaxel: pharmacokinetic and pharmacodynamic interactions in advanced breast cancer. Ann Oncol 13: 919-927

Ganem G, Tubiana-Hulin M, Fumoleau P, Combe M, Misset JL, Vannetzel JM, Bachelot T, De Ybarlucea LR, Lotz V, Bendahmane B, Dieras V (2003) Phase II trial combining docetaxel and doxorubicin as neoadjuvant chemotherapy in patients with operable breast cancer. Ann Oncol 14: $1623-1628$

Gianni L, Baselga J, Eiermann W, Guillen Porta V, Semiglazov V, GarciaConde J, Zambetti M, Valagussa P, Bonadonna G (2002) First report of the European Cooperative Trial in Operable Breast Cancer (ECTO): effects of primary systemic therapy (PST) on local - regional disease. Proc Am Soc Clin Oncol 21: 34 (abstract 132)

Gradishar WJ (1997) Docetaxel as neoadjuvant chemotherapy in patients with stage III breast cancer. Oncology 11: 15-18

Hamm J, Wilson J, Lembersky BC, Robidoux A, Raymond J, Kardinal C, DiNunno L, Melemed A, Geyer Jr CE, Paik S, Wolmark N (2003) Neoadjuvant chemotherapy with gemcitabine $(G)$, epirubicin(E), and paclitaxel(T) in locally advanced breast cancer(LABC): a phase II trial of the NSABP Foundation Research Group. Breast Cancer Res Treat 82: S53 (abstract 235)

Hortobagyi G, Buzdar AU (1997) Locally advanced breast cancer. In Textbook of Breast Cancer. A Clinical Guide to Therapy, Bonadonna G, Hortobagyi GN, Gianni AM (eds) pp 155-168. Martin Dunitz: London Kaufmann M, von Minckwitz G, Smith R, Valero V, Gianni L, Eiermann W, Howell A, Costa SD, Beuzeboc P, Untch M, Blohmer JU, Sinn HP, Sittek R, Souchon R, Tulusan AH, Volm T, Senn HJ (2003) International Expert Panel on the use of primary (preoperative) systemic treatment of operable breast cancer: review and recommendations. J Clin Oncol 21: $2600-2608$

Kuerer HM, Newman LA, Smith TL, Ames FC, Hunt KK, Dhingra K, Theriault RL, Singh G, Binkley SM, Sneige N, Buchholz TA, Ross MI, McNeese MD, Buzdar AU, Hortobagyi GN, Singletary SE (1999) Clinical course of breast cancer patients with complete pathological tumor and axillary ymph node response to doxorubicin-based neoadjuvant chemotherapy. J Clin Oncol 17: 460-469

Lebowitz PF, Eng-Wong J, Swain SM, Berman A, Merino MJ, Chow CK, Venzon D, Zia F, Danforth D, Liu E, Zujewski J (2004) A phase II trial of neoadjuvant docetaxel and capecitabine for locally advanced breast cancer. Clin Cancer Res 10: 6764-6769

Makris A, Powles TJ, Dowsett M, Osborne CK, Trott PA, Fernando IN, Ashley SE, Ormerod MG, Titley JC, Gregory RK, Allred DC (1997) Prediction of response to neoadjuvant chemoendocrine therapy in primary breast carcinomas. Clin Cancer Res 3: 593-600

Martin M, Pienkowski T, Mackey J, Pawlicki M, Guastalla JP, Weaver C, Tomiak E, Al-Tweigeri T, Chap L, Juhos E, Guevin R, Howell A, Fornander T, Hainsworth J, Coleman R, Vinholes J, Modiano M, Pinter T, Hugh J, Nabholtz JM, Loret C, Rupin M, Blitz S, Riva A, Vogel C, on behalf of the BCIRG 001 Investigators (2003) TAC improves disease free survival and overall survival over FAC in node positive early breast cancer patients, BCIRG 001: 55 months follow-up. Breast Cancer Res Treat 82(Suppl 1) (abstract 43)

Mauri D, Pavlidis N, Ioannidis JP (2005) Neoadjuvant $v s$ adjuvant systemic treatment in breast cancer: an a-analysis. J Natl Cancer Inst 97: 188-194 Mauriac L, MacGrogan G, Avril A, Durand M, Floquet A, Debled M, Dilhuydy JM, Bonichon F (1999) Neoadjuvant chemotherapy for operable breast carcinoma larger than $3 \mathrm{~cm}$ : a unicentre randomised trial with a 124-month follow-up. Institut Bergonie Bordeaux Groupe Sein (IBBGS). Ann Oncol 10: 47-52
Petit T, Borel C, Ghnassia JP, Rodier JF, Escande A, Mors R, Haegele P (2001) Chemotherapy response of breast cancer depends on HER-2 status and anthracycline dose intensity in the neoadjuvant setting. Clin Cancer Res 7: 1577-1581

Pierga JY, Mouret E, Dieras V, Laurence V, Beuzeboc P, Dorval T, Palangie T, Jouve M, Vincent-Salomon A, Scholl S, Extra JM, Asselain B, Pouillart P (2000) Prognostic value of persistent node involvement after neoadjuvant chemotherapy in patients with operable breast cancer. Br J Cancer 83: $1480-1487$

Pusztai L, Ayers M, Symmans FW, Damokosh A, Hess K, Valero V, Clark E, Ross J, Hortobagyi GN, Stec J (2003) Emerging science: prospective validation of gene expression profiling-based prediction of complete pathologic response to neoadjuvant paclitaxel/FAC chemotherapy in breast cancer. Proc Am Soc Clin Oncol 22: 1 (abstract 1)

Schneeweiss A, Huober J, Sinn HP, von Fournier D, Rudlowski C, Beldermann F, Krauss K, Solomayer E, Hamerla R, Wallwiener D, Bastert G (2004) Gemcitabine, epirubicin and docetaxel as primary systemic therapy in patients with early breast cancer: results of a multicentre phase I/II study. Eur J Cancer 40: 2432-2438

Scholl SM, Fourquet A, Asselain B, Pierga JY, Vilcoq JR, Durand JC, Dorval T, Palangie T, Jouve M, Beuzeboc P, Garcio-Giralta E, Salmon RJ, de la Rochefordière A, Campana F, Pouillart P (1994) Neoadjuvant $v s$ adjuvant chemotherapy in premenopausal patients with tumours considered too large for breast conserving surgery: preliminary results of a randomised trial: S6. Eur J Cancer 30: 645-652

Smith IC, Heys SD, Hutcheon AW, Miller ID, Payne S, Gilbert FJ, Ah-See AK, Eremin O, Walker LG, Sarkar TK, Eggleton SP, Ogston KN (2002) Neoadjuvant chemotherapy in breast cancer: significantly enhanced response with docetaxel. J Clin Oncol 20: 1456-1466

Smith IE, A'Hern RP, Coombes GA, Howell A, Ebbs SR, Hickish TF, O'Brien ME, Mansi JL, Wilson CB, Robinson AC, Murray PA, Price CG, Perren TJ, Laing RW, Bliss JM, TOPIC Trial Group (2004) A novel continuous infusional 5-fluorouracil-based chemotherapy regimen compared with conventional chemotherapy in the neo-adjuvant treatment of early breast cancer: 5 year results of the TOPIC trial. Ann Oncol 15: 751-758

Smith IE, Walsh G, Jones A, Prendiville J, Johnston S, Gusterson B, Ramage F, Robertshaw H, Sacks N, Ebbs S (1995) High complete remission rates with primary neoadjuvant infusional chemotherapy for large early breast cancer. J Clin Oncol 13: 424-429

Ueno NT, Buzdar AU, Singletary SE, Ames FC, McNeese MD, Holmes FA, Theriault RL, Strom EA, Wasaff BJ, Asmar L, Frye D, Hortobagyi GN (1997) Combined-modality treatment of inflammatory breast carcinoma: twenty years of experience at MD Anderson Cancer Center. Cancer Chemother Pharmacol 40: $321-329$

van de Vijver MJ, He YD, van't Veer LJ, Dai H, Hart AA, Voskuil DW, Schreiber GJ, Peterse JL, Roberts C, Marton MJ, Parrish M, Atsma D, Witteveen A, Glas A, Delahaye L, van der Velde T, Bartelink H, Rodenhuis S, Rutgers ET, Friend SH, Bernards R (2002) A geneexpression signature as a predictor of survival in breast cancer. $N$ Engl J Med 347: 1999-2009

van der Hage JA, van de Velde CJ, Julien JP, Tubiana-Hulin M, Vandervelden C, Duchateau L (2001) Preoperative chemotherapy in primary operable breast cancer: results from the European Organization for Research and Treatment of Cancer Trial 10902. I Clin Oncol 19: $4224-4237$

van't Veer LJ, Dai H, Van De Vijer MJ, He YD, Hart AA, Mao M, Peterse HL, van der Kooy K, Marton MJ, Witteveen AT, Schreiber GJ, Kerkhoven RM, Roberts C, Linsley PS, Bernards R, Friend SH (2002) Gene expression profiling predicts clinical outcome of breast cancer. Nature 415: $530-536$

von Minckwitz G, Raab G, Blohmer JU, Gerber B, Lohr A, Costa SD, Eidtmann H, Hilfrich J, Jackisch C, Kaufmann M, the German Breast Group (GBG) (2003) In vivo chemosensitivity-adapted neoadjuvant chemotherapy (docetaxel-doxorubicin-cyclophosphamide followed by vinorelbine-capecitabine salvage therapy) in patients with primary breast cancer: results of the GEPAR-TRIO randomized pilot study. Breast Cancer Res Treat 82: S54 (abstract 236)

Zielinski C, Beslija S, Mrsic-Krmpotic Z, Jassem J, Wiltschke C, Kahan Z, Grgic M, Tzekova V, Inbar M, Brodowicz T (2003) Gemcitabine/ epirubicin/paclitaxel (GET) vs 5-fluorouracil/epirubicin/cyclophosphamide (FEC) as first-line treatment in metastatic breast cancer (MBC): demographics of a randomized, multicenter phase III trial of the Central European Cooperative Oncology Group (CECOG). Proc Am Soc Clin Oncol 22: 7, 26a 